\title{
Geologic and Geoarchaeological Mapping of the Sanctuary of Zeus, Peloponnesus, Greece
}

\author{
George H. Davis \\ Department of Geosciences, The University of Arizona, Tucson, Arizona 85721, USA
}

\section{BACKGROUND}

The Sanctuary of Zeus, Mount Lykaion, is located in the Peloponnesus of Greece. It lies $14 \mathrm{~km}$ west of Megalopolis and $33 \mathrm{~km}$ southeast of Olympia (Fig. 1).

From at least as far back as the fifteenth century B.C., and extending into first century B.C., this sanctuary was the site of Zeuscult activities, details of which are described in the ancient literature and in the findings of early twentieth-century excavations carried out by archaeologists associated with the Greek Archaeological Service (Romano and Voyatzis, 2014, 2015). Since 2004, this sanctuary has been the focus of detailed and comprehensive inquiry by the Mount Lykaion Excavation and Survey Project, a joint effort of the American School of Classical Studies (Athens), the Greek Archaeological Service, and the University of Arizona (see Acknowledgments below). As project geologist I have carried out detailed geological mapping of this site, with the primary goal of describing the influence of the geology and tectonics on site selection for this uncommon mountaintop Zeus-cult sanctuary, and for interpreting the distribution of its built structures and monuments. Mapping and analysis have revealed that the archaeological elements of the sanctuary were positioned and/or exploited where landscape, bedrock, and/or geologic structures were amenable to intended function (Davis, 2017).

\section{COMPONENTS OF THIS CONTRIBUTION}

This GSA Map and Chart Series contribution has five components: (A) summary; (B) Geologic Map; (C) Geoarchaeological Map; (D) Map of Field Stations; and (E) spreadsheet of formation identification and bedding readings.

\section{STRATIGRAPHY}

The basic stratigraphy of the region was established by Lalechos $(1973,1974)$ and Papadopoulos (1997). They framed the stratigraphic column shown in Figure 2D. They recognized that these four bedrock formations belong to the Pindos Unit. Each author mapped areas of $\sim 500 \mathrm{~km}^{2}$ at 1:50,000-scale mapping. I carried out geologic mapping at a much larger scale (1:2000) and for a much smaller area $\left(\sim 15 \mathrm{~km}^{2}\right)$. I split the "Limestones" into two distinctive limestone-dominated formations (Fig. 2E), and I assigned informal names to each of five formations. (1) The Chert Series Beds formation (Jurassic to Lower Cretaceous) is composed of multicolored radiolarian chert layers in alternations with fine-grained sandstone in the lower part. Upwards, coarse-grained sandstones prevail with interbeds of

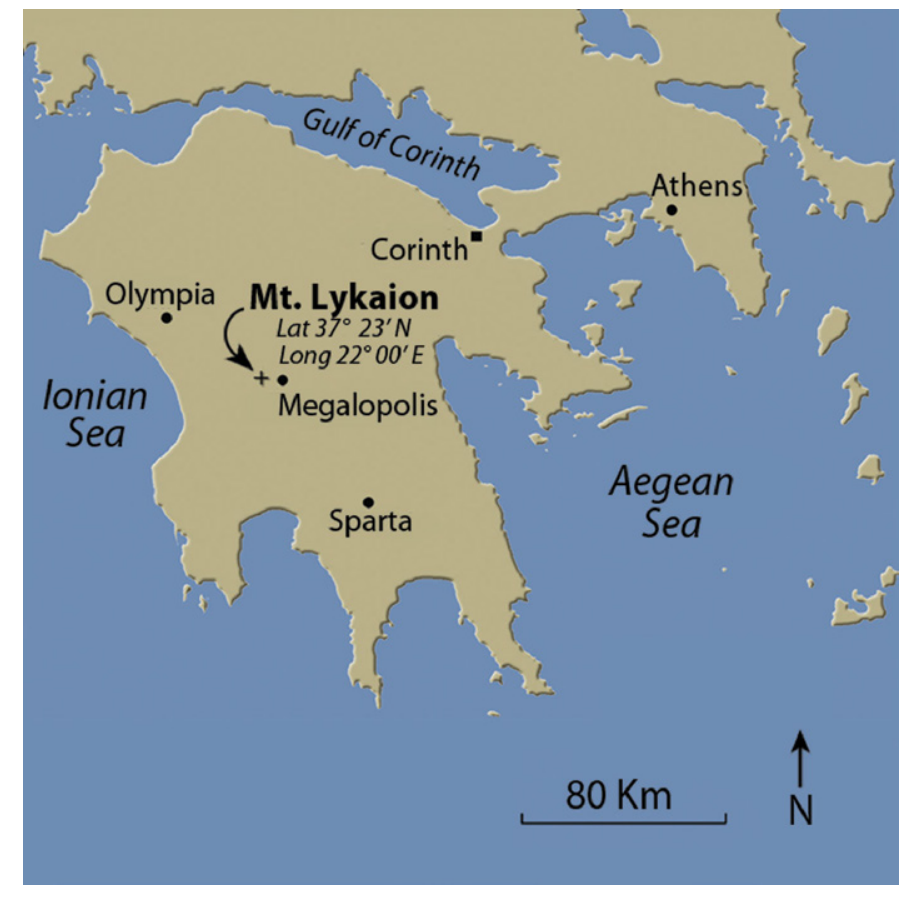

Figure 1. Location map showing Mount Lykaion in relation to the greater Peloponnese and mainland Greece. Geographical coordinates provided for Sanctuary of Zeus.

Davis, G.H., compiler, 2018, Geologic and Geoarchaeological Mapping of the Sanctuary of Zeus, Peloponnesus, Greece: Geological Society of America Digital Map and Chart Series 23, 7 p., https://doi.org/10.1130/2018.DMCH023. For permission to copy, contact editing @ geosociety.org. ( 2018 The Geological Society of America. All rights reserved. 


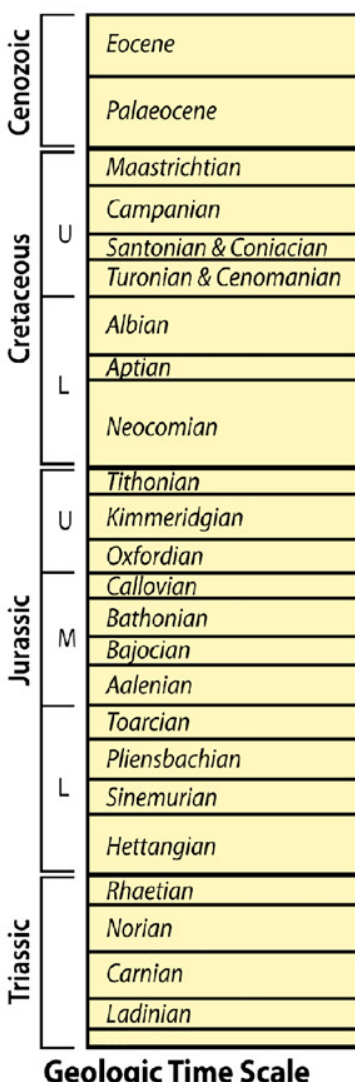

Geologic Time Scale
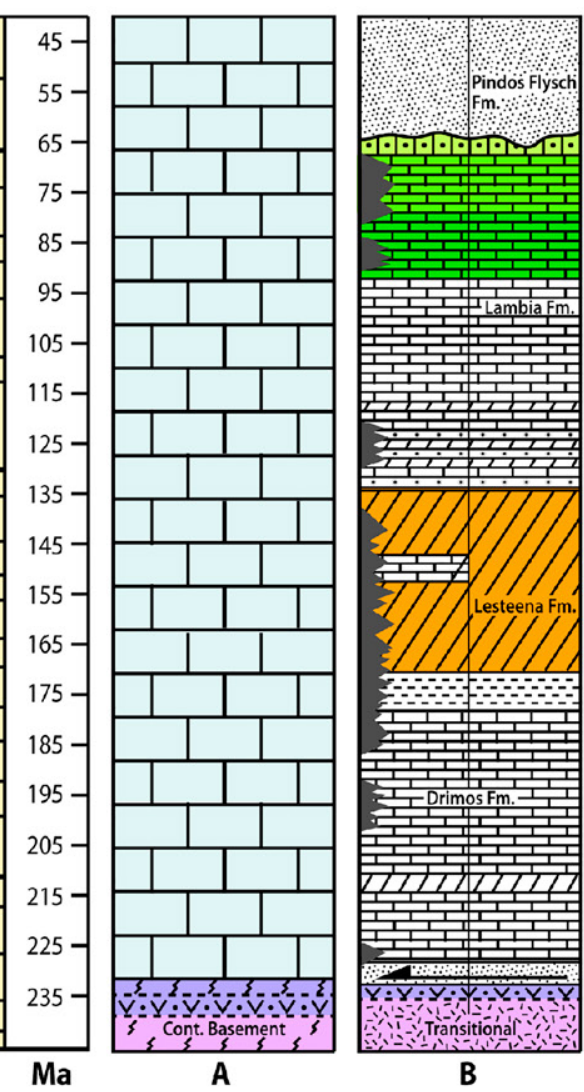
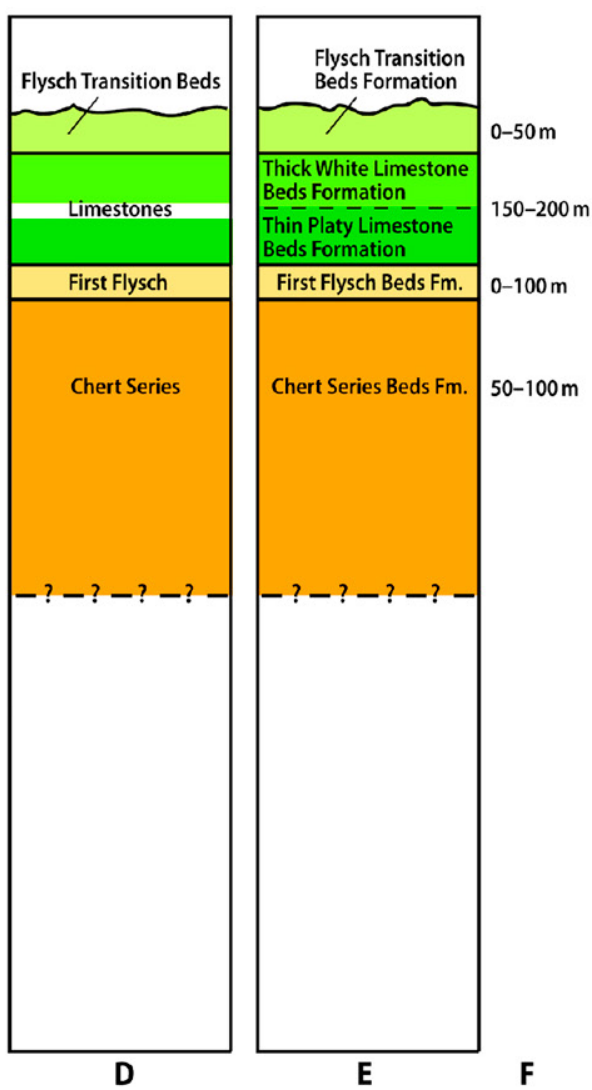

Figure 2. Pindos Basin formations and ages. (A) Carbonate platform sediments deposited on rift margin of basin. (B) Pindos Basin formations and (C) members, from Degnan and Robertson (1998). Stratigraphic nomenclature of (D) Lalechos (1973, 1974) and Papadopoulos (1997), and (E) Davis (2009). (F) The approximate thicknesses of formations in Mount Lykaion area. Overall figure adapted from Degnan and Robertson (1998, their figure 16, p. 66).

radiolarian chert, red marl, and fine-grained limestone. (2) The First Flysch Beds formation (Cenomanian to Lower Turonian) is a sequence of brownish or greenish, fine-grained to coarsegrained sandstones with some interbeds of red marls (clayey limestones). $(3,4)$ The Limestone Beds formation (Turonian to Maastrichtian) consists of platy to bedded, multicolored limestone with layers or nodules of red-black chert. In the upper parts, clayey limestone (marls) and red mudstone are interstratified, as well as minor sandstone. (5) The Flysch Transition Beds formation (Maastrichtian and Paleocene) consists of alternations of thin-platy to bedded limestone, with layers or nodules of chert and clayey limestone (marl) and red marl in the lower part. Detailed descriptions and photographs of the map units may be found in Davis (2009, 2014).

The Pindos Unit was deposited in a deep, narrow, oceanic basin adjacent to Apulian and Pelagonian (African microplate) rift shoulders, on which shallow-water carbonate platforms were deposited (see Fig. 2A). Sediments deposited in the Pindos Basin from Late Triassic to Early Cretaceous were radiolarian cherts and other siliceous pelagic deposits interlayered with arrivals of turbidity-current-derived siliciclastics (Degnan and Robertson, 1991, 1998). During the Late Cretaceous, there was a shift to deposition of pelagic and hemipelagic carbonates and carbonate turbidites (Degnan and Robertson, 1998). In Late Cretaceous and Paleocene, the Pindos Basin was tectonically inverted (Degnan and Robertson, 1991, 1998, 2006; Piper, 2006; Skourlis and Doutsos, 2003).

\section{STRUCTURAL GEOLOGY}

The Sanctuary of Zeus occupies Agios Elias ( 1400 m), the second highest peak of Mount Lykaion. The upper part of Agios Elias is a thrust klippe. The regional thrust fault (Lykaion thrust), which defines the base of the klippe, dips $10^{\circ} \mathrm{E}$ and discretely separates the upper and lower levels of the Sanctuary of Zeus (Davis, 2009). The lower plate of the Lykaion thrust is marked by a number of large, northerly trending, gently plunging, upright to slightly overturned anticlines and synclines. The upper plate of the Lykaion thrust is largely homoclinal and gently dipping, although conspicuously broken by high-angle normal faults. Evidence for active faulting is clear along the eastern margin of Agios Elias, where Agios Elias is stepped down eastward, ground-rupture fissuring is abundant, and a major active landslide has been accumulating. Details of the nature of 
the structural geology of the map area are available in Davis (2009, 2014).

The geological mapping presented here was used as a basis for developing a three-dimensional (3D) structural model for Mount Lykaion and the Sanctuary of Zeus (see Acknowledgments). Figure $3 \mathrm{~A}$ shows one of six geological cross sections that were constructed as a control for the 3D model proper (Fig. 3B). The cross section reveals the major thrust fault (Lykaion thrust) that demarcates the base of the Agios Elias klippe. The upper level of the Sanctuary of Zeus occupies this klippe. Beneath the Lykaion thrust are macroscopically folded Jurassic through Paleocene strata. The geological cross section captures just one of the several high-angle normal faults that cut and extend the thrust relationships. Note that this fault, the Cairn Hill normal fault, cuts and offsets the Lykaion thrust fault.
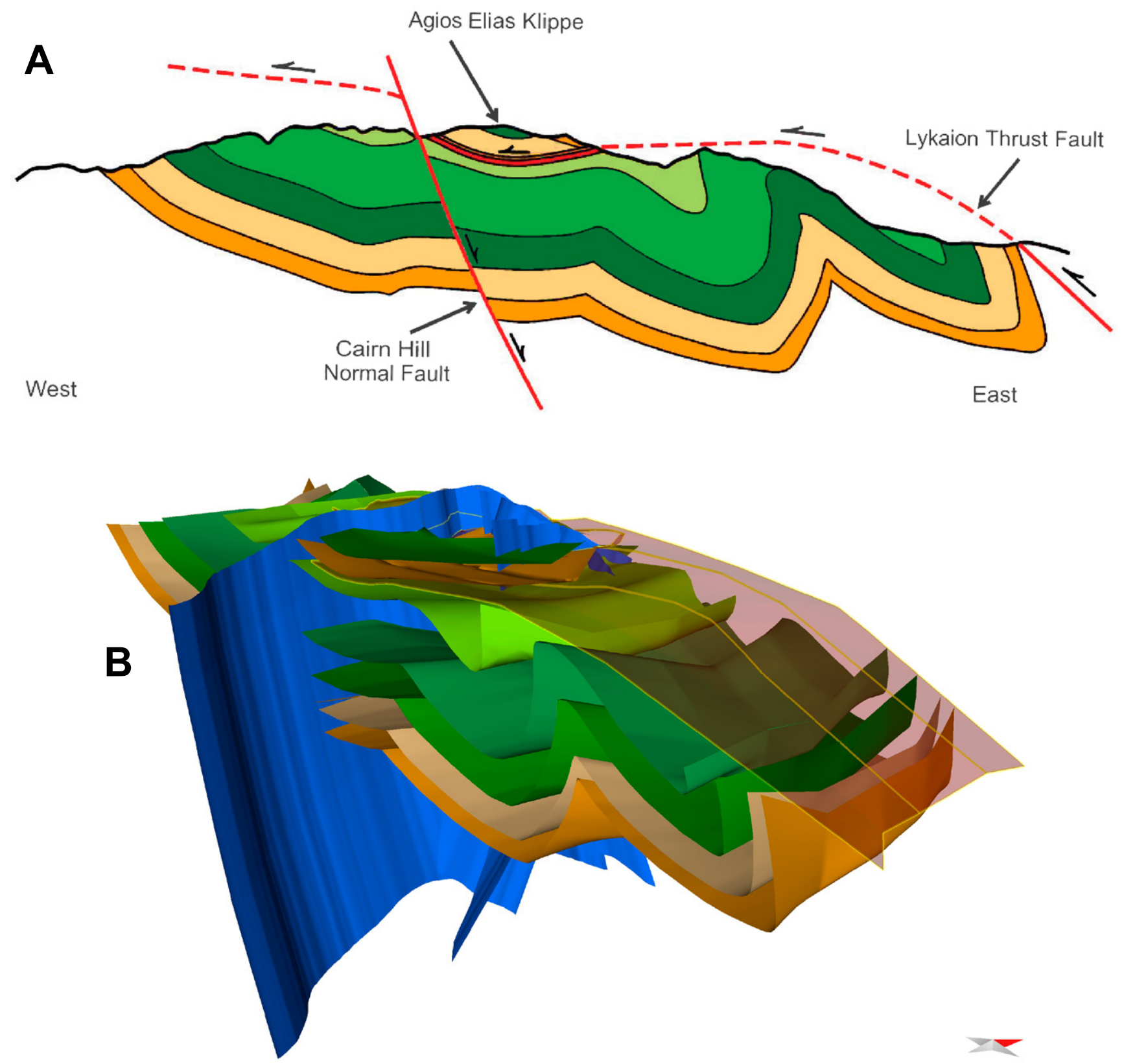

Figure 3. (A) Geologic cross section of the Sanctuary of Zeus, which identifies the location of the Lykaion thrust fault, the Cairn Hill normal fault, and the Agios Elias klippe. Formations are Chert Series Beds formation (orange), First Flysch Beds formation (tan), Thin Platy Limestone Beds formation (dark green), Thick White Limestone Beds formation (medium green), and Flysch Transition Beds formation (light green). (B) True 3D model of the structural geology of the Sanctuary of Zeus, constructed by Midland Valley Exploration, Ltd. based on G.H. Davis ArcMap GIS data. Same color coding as in A. 
As referenced above, the regional thrusting and macroscopic folding related to the Agios Elias klippe occurred as a result of inversion tectonics, when the Jurassic to early Cenozoic Pindos Basin was closed and uplifted. Since the mid-Cenozoic, the Agios Elias klippe and the sanctuary overall have been impacted by normal faulting associated with tectonic extension and stretching of Greece and the Aegean region. In fact, geological mapping revealed that the Sanctuary of Zeus is marked by normal faults that cut and displace the Lykaion thrust. Moreover, the sanctuary contains an active fault and fissure field, which helps feed a large landslide below. The nature of the interplay of faulting and folding is revealed in Figure 3B, which captures the 3D properties of the stratigraphy and structure.

\section{GEOARCHAEOLOGY}

The very earliest evidence for Zeus-cult activity is found in the upper level of the sanctuary, which includes the ash altar, temenos, proto-stadium, and some quarries (Romano and Voyatzis, 2015). The lower sanctuary reveals built structures (stoa, administration building, fountain house, corridor, seats, bath) and activity areas (hippodrome, processional way, horse pasture) that appear to have been initiated in the seventh century B.C. (Romano and Voyatzis, 2014). Quite a number of geological factors favored the Zeus-cult placement of built structures and activity areas in close relationship to Agios Elias (Davis, 2017), including the plentiful natural springs emanating from the Lykaion thrust fault. The singularly most important geoarchaeological control is the Agios Elias klippe, which indeed 'rides on' the Lykaion thrust (Davis, 2017). In Figure 4, I present a geoarchaeological column, which shows the relationships of the individual archaeological elements and activity areas to the stratigraphy and structure of Mount Lykaion and the Sanctuary of Zeus (Davis et al., 2009; Similox-Tohon et al., 2009, 2011).

\section{AIDS TO EXPLORING THE MAPS}

The Geologic and Geoarchaeological Maps for this site can be actively scaled (reduced, enlarged) as they are examined. As I explore these maps at large scale, I find it useful to also have small PDF versions of each map available, so that I have a reference in migrating to targets of interest. For this reason I have included small versions of the Geologic Map (Fig. 5) and the Geoarchaeological Map (Fig. 6), herein.

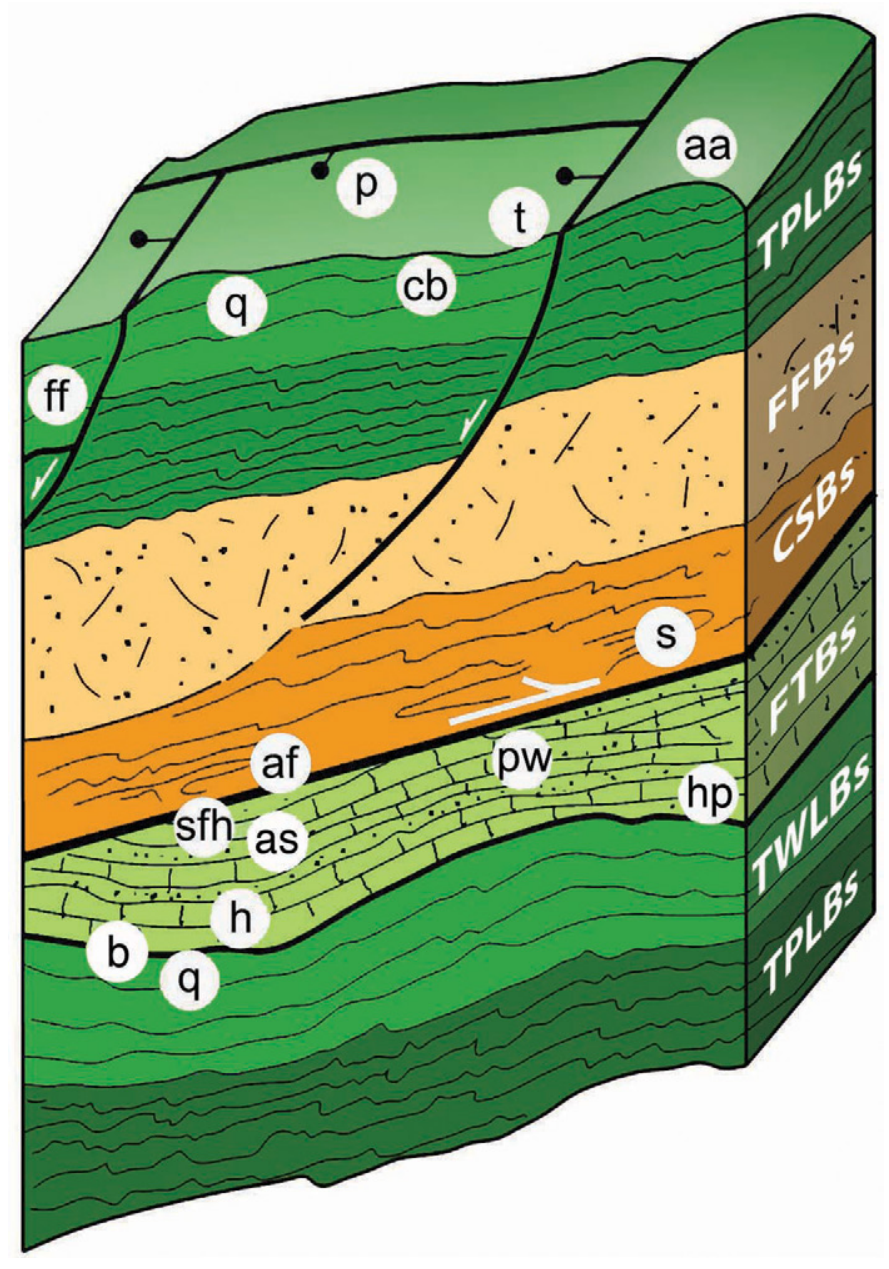

Figure 4. Geoarchaeological column created to underscore the relation of archaeological elements to the geology. Colors correspond to explanation on maps (Figs. 5 and 6). Position of Lykaion thrust fault is shown (note white arrow). Abbreviations are as follows: aa-ash altar; af-Agnos fountain; as-administration building and seats; $b$ - bath; $c b$ - column bases; ff—-fissure field; h-hippodrome; hphorse pasture; $\mathrm{p}$ - proto-stadium; $\mathrm{pw}$ - processional way; q-quarry; s-spring; sfh-stoa and fountain house; $t$ - temenos. CSBs-Chert Series Beds formation; FFBs-First Flysch Beds formation; TPLBs-Thin Platy Limestone Beds formation; TWLBs-Thick White Limestone Beds formation; FTBs-Flysch Transition Beds formation. 


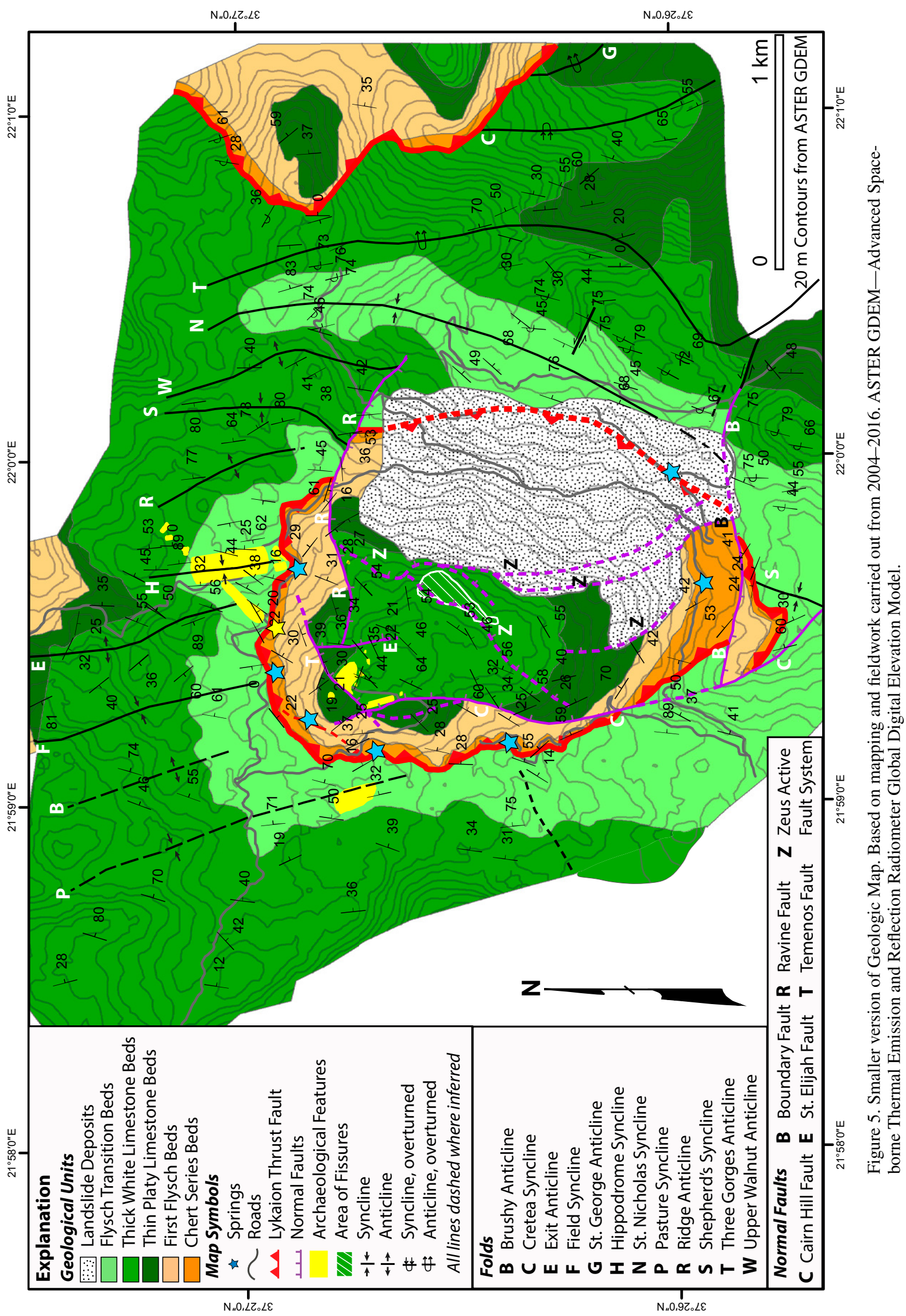




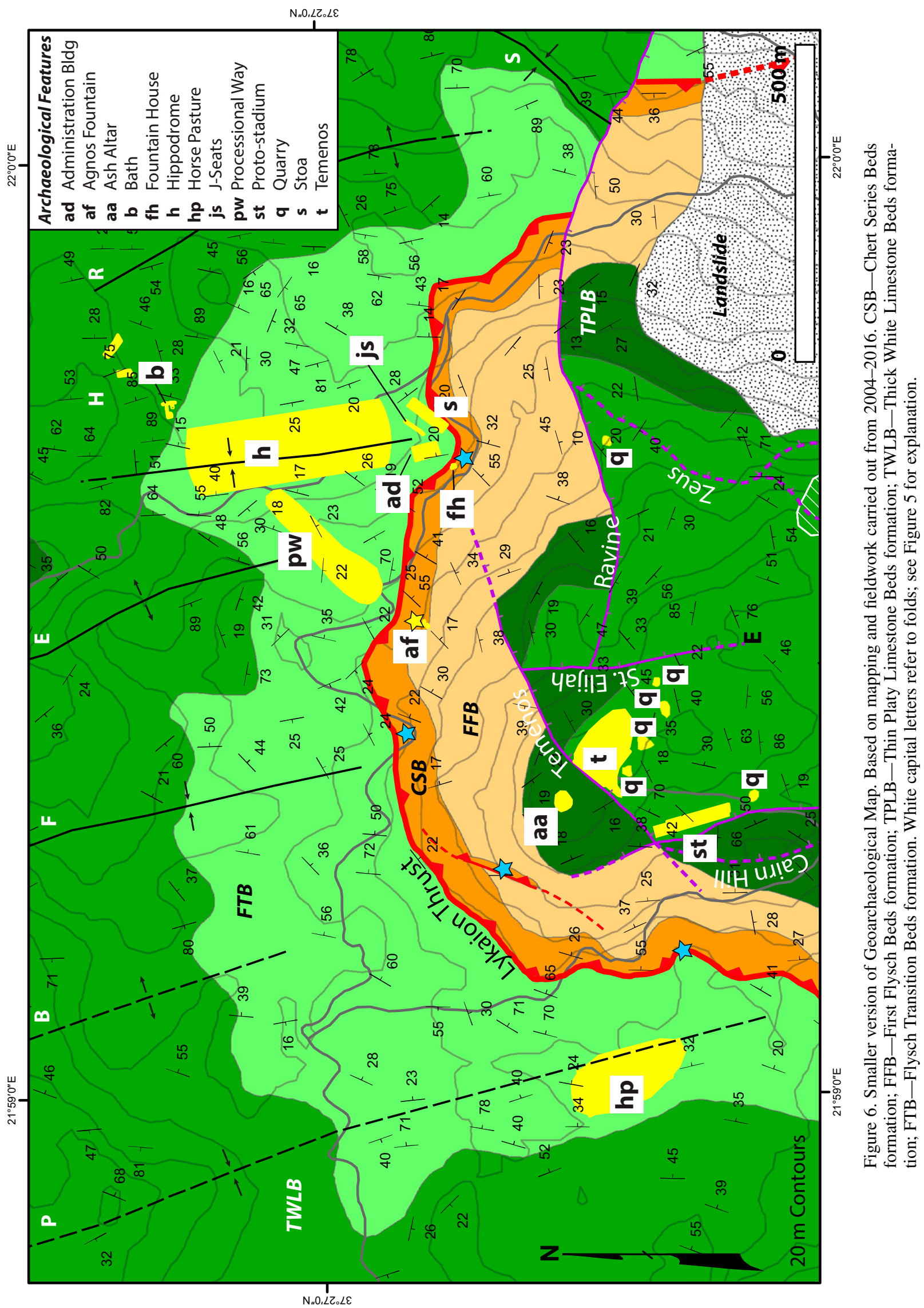




\section{ACKNOWLEDGMENTS}

I am indebted to David Romano and Mary Voyatzis, co-directors of the Mount Lykaion Excavation and Survey Project, for inviting me to serve as geologist on the project and for introducing me to the world of classical archaeology. I also wish to express my gratitude to my field assistants, who aided me enormously in the geological mapping, namely, Tom Fenn (2004, 2005), Randy Goosen (2007), Phil Nickelson (2008), Karl Yares (2009), Kyle Maloney (2010), George Faidon Papakonstantinou (2011), and Alex Weber $(2015,2016)$. Throughout my geological mapping I employed ArcMap GIS to build and manage the data and contact relationships. For this I depended on the skill and expertise of graduate-student research assistants, particularly Tom Fenn, Meridith Reifschneider, and Katherine Guns. As a research associate with Midland Valley Exploration, Ltd. (MVE; Glasgow), I also benefited from Midland Valley's Move software packages in 3D modeling of the geology and topography of the Mount Lykaion study area. Colleagues in MVE who carried out the modeling include Alan Gibbs, Roddy Muir, Hugh Anderson, Francesco Borraccini, Steve Clelland, Jenny Ellis, Andrea Moccia, and Dominique Similox-Tohon. Lastly, this project would not have been possible without the generous permission and support of the Ephorate of Antiquities of Arcadia, directed by Anna Karapanagiotou, Greek Ministry of Culture, and the American School of Classical Studies at Athens.

\section{REFERENCES CITED}

Davis, G.H., 2009, Geology of the Sanctuary of Zeus, Mount Lykaion, southern Peloponnesos, Greece: Journal of the Virtual Explorer, v. 33, 58 p.

Davis, G.H., 2014, Quasi-flexural folding of pseudo-bedding: Geological Society of America Bulletin, v. 126, p. 680-701, https://doi.org/10.1130 /B30963.1.

Davis, G.H., 2017, Tectonic klippe served the needs of cult worship, Sanctuary of Zeus, Mt. Lykaion, Peloponnese, Greece: GSA Today, v. 7, no. 12, p. 4-9, https://doi.org/10.1130/GSATG353A.1.

Davis, G.H., Reifschneider, M.A., Borraccini, F., and Similox-Tohon, D., 2009, Iterative geologic mapping and 3D structural modeling to identify spatial inconsistencies and create accurate visualization framework for geo- archaeological interpretations: Mt. Lykaion (Greece) Sanctuary of Zeus case study: Part 1, Mapping, Geological Society of America Abstracts with Programs, v. 41, no. 7, abstract 54-12, p. 167-168.

Degnan, P.J., and Robertson, A.H.F., 1991, Tectonic and sedimentary evolution of the western Pindos Ocean: N.W. Peloponnese, Greece: Bulletin of the Geological Society of Greece, v. 25, p. 263-273.

Degnan, P.J., and Robertson, A.H.F., 1998, Mesozoic-early Tertiary passive margin evolution of the Pindos ocean (NW Peloponnese, Greece): Sedimentary Geology, v. 117, p. 33-70, https://doi.org/10.1016/S0037-0738 (97)00113-9.

Degnan, P.J., and Robertson, A.H.F., 2006, Synthesis of the tectonic-sedimentary evolution of the Mesozoic-early Cenozoic Pindos ocean: Evidence from the NW Peloponnese, Greece, in Robertson, A.H.F., and Mountrakis, D., eds., Tectonic Development of the Eastern Mediterranean Region: Geological Society, London, Special Publication 260, p. 467-491, https:// doi.org/10.1144/GSL.SP.2006.260.01.19.

Lalechos, N., 1973, Geologic Map of the Greece Kato Fighalia Sheet (1:50,000): National Institute of Geological and Mining Research, Athens, Greece.

Lalechos, N., 1974, The Geological Structure of the Central-Western Peloponnese: Athens, National Institute of Geological and Mining Research, Geological Reconnaissance Paper No. 53, 94 p.

Papadopoulos, P., 1997, Geological Map of the Megalopolis Sheet (1:50,000): National Institute of Geology and Mineral Exploration, Athens, Greece.

Piper, D.J.W., 2006, Sedimentology and tectonic setting of the Pindos Flysch of the Peloponnese, Greece, in Robertson, A.H.F., and Mountrakis, D., eds., Tectonic Development of the Eastern Mediterranean Region: Geological Society, London, Special Publication 260, p. 493-505, https://doi.org/10 .1144/GSL.SP.2006.260.01.20.

Romano, D.G., and Voyatzis, M.E., 2014, Mt. Lykaion Excavation and Survey Project: The Upper Sanctuary: Hesperia, v. 83, p. 569-652.

Romano, D.G., and Voyatzis, M.E., 2015, Mt. Lykaion Excavation and Survey Project, Part 2: The Upper Sanctuary: Hesperia, v. 84, p. 207-276, https:// doi.org/10.2972/hesperia.84.2.0207.

Similox-Tohon, D., Scherrenberg, A., Clelland, S., and Davis, G.H., 2009, Iterative geologic mapping and 3D structural modeling to identify spatial inconsistencies and create accurate visualization framework for geoarchaeological interpretations: Mt. Lykaion (Greece) Sanctuary of Zeus case study: Part 2, Modeling: Geological Society of America Abstracts with Programs, v. 41, no. 7, abstract 54-13, p. 168.

Similox-Tohon, D., Clelland, S., Moccia, A., and Davis, G.H., 2011, 3D structural model building-The Mt. Lykaion (Greece) Sanctuary of Zeus case study: Geological Society of America Abstracts with Programs, v. 43, no. 5 , p. 302.

Skourlis, K., and Doutsos, T., 2003, The Pindos fold-and-thrust belt (Greece): Inversion kinematics of a passive continental margin: International Journal of Earth Sciences, v. 92, p. 891-903, https://doi.org/10.1007/s00531 $-003-0365-4$.

Manuscript Accepted by the Society 17 November 2017 